\title{
An experimental study on short-term changes in the anaerobic oxidation of methane in response to varying methane and sulfate fluxes
}

\author{
G. Wegener ${ }^{1}$ and A. Boetius ${ }^{1,2}$ \\ ${ }^{1}$ Max Planck Institute for Marine Microbiology, Bremen, Germany \\ ${ }^{2}$ Alfred Wegener Institute for Polar and Marine Research, Bremerhaven, Germany \\ Received: 23 June 2008 - Published in Biogeosciences Discuss.: 24 July 2008 \\ Revised: 29 April 2009 - Accepted: 29 April 2009 - Published: 18 May 2009
}

\begin{abstract}
A major role in regulation of global methane fluxes has been attributed to the process of anaerobic oxidation of methane (AOM), which is performed by consortia of methanotrophic archaea and sulfate reducing bacteria. An important question remains how these energy limited, slow growing microorganisms with generation times of 3-7 months respond to rapid natural variations in methane fluxes at cold seeps. We used an experimental flow-through column system filled with cold seep sediments naturally enriched in methanotrophic communities, to test their responses to short-term variations in methane and sulfate fluxes. At stable methane and sulfate concentrations of $\sim 2 \mathrm{mM}$ and $28 \mathrm{mM}$, respectively, we measured constant rates of AOM and sulfate reduction (SR) for up to 160 days of incubation. When percolated with methane-free medium, the anaerobic methanotrophs ceased to produce sulfide. After a starvation phase of 40 days, the addition of methane restored former AOM and SR rates immediately. At methane concentrations between $0-2.3 \mathrm{mM}$ we measured a linear correlation between methane availability, AOM and SR. At constant fluid flow velocities of $30 \mathrm{~m} \mathrm{yr}^{-1}$, ca. $50 \%$ of the methane was consumed by the anaerobic methanotrophic (ANME) population at all concentrations tested. Reducing the sulfate concentration from 28 to $1 \mathrm{mM}$, a decrease in AOM and SR by $50 \%$ was observed, and $45 \%$ of the methane was consumed. Hence, the marine anaerobic methanotrophs (ANME) are capable of oxidizing substantial amounts of methane over a wide and variable range of fluxes of the reaction educts.
\end{abstract}

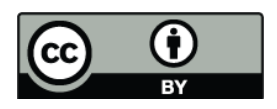

Correspondence to: $\mathrm{G}$. Wegener (gwegener@mpi-bremen.de)

\section{Introduction}

Between 5 and $10 \%$ of the organic matter deposited on the seafloor is converted to methane by a sequence of microbial processes in which methane production is the terminal degradation step (Canfield, 1993; Canfield et al., 2005). The concentrations of dissolved methane in the ocean range from a few $\mathrm{nM}$ in seawater to about hundred $\mathrm{mM}$ in hydrate-bearing subsurface sediments (Reeburgh, 2007); and submarine gas hydrates bind more methane than all other reservoirs on earth (Milkov, 2004). However methane emission from the ocean is rather low, contributing an estimated 3 to $5 \%$ of the atmospheric methane budget. This is due to the consumption of methane by anaerobic and aerobic microorganisms in the seabed which represent an effective filter against this potential greenhouse gas (Reeburgh, 1996, 2007).

Due to the limited penetration of oxygen into the seabed, AOM is considered the globally more important sink for methane in the ocean compared to aerobic oxidation of methane (Hinrichs and Boetius, 2002; and literature therein). The net reaction for AOM with sulfate is:

$$
\mathrm{CH}_{4}+\mathrm{SO}_{4}^{2-} \longrightarrow \mathrm{HCO}_{3}^{-}+\mathrm{HS}^{-}+\mathrm{H}_{2} \mathrm{O}
$$

This process is performed by consortia of methanotrophic archaea and sulfate reducing bacteria (Boetius et al., 2000; Orphan et al., 2001). Metagenomic and proteomic studies support the hypothesis that some pathways in AOM are based on a reversal of methanogenesis, since several key enzymes of the anaerobic methanotrophs are closely related to those of methanogens (Hallam at al., 2004; Krüger et al., 2005; Meyerdierks et al., 2005). It was recently shown that the assimilation of carbon by both consortia partners is directly coupled

Published by Copernicus Publications on behalf of the European Geosciences Union. 
to AOM (Wegener et al., 2008a), however the metabolic link between the consortia partners remains unknown.

In vitro incubation studies with ANME communities enriched with sulfate reducer medium showed that AOM rates predominantly depend on methane concentrations, and suggested extraordinarily high apparent methane half-saturation constants ( $\mathrm{k}_{M}$-values) in the range of several $\mathrm{mM}$ (Nauhaus et al., 2002, 2005, 2007). The $\mathrm{k}_{M}$ of AOM for methane and sulfate consumption is a relevant factor in the efficiency of the microbial filter against methane in the seabed. In diffusive systems methane is consumed within narrow sulfate methane transition zones (SMTZ) in the seabed and the efficiency of the microbial filter against methane is $100 \%$. In the SMTZ methane oxidation rates range from a few pmol cm ${ }^{-3}$ day $^{-1}$ (e.g., Blake Ridge; Wellsbury et al., 2000), to tens of $\mathrm{nmol} \mathrm{cm}^{-3}$ day $^{-1}$ (e.g. $30 \mathrm{nmol} \mathrm{g}^{-1}$ day $^{-1}$ in coastal sediments of Monterey Bay (Girguis et al., 2003)). In advective systems (cold seeps) with high methane concentrations and flow velocities of $<0.1 \mathrm{~m} \mathrm{yr}^{-1} \mathrm{AOM}$ rates increase to hundreds of nmol cm${ }^{-3} \mathrm{day}^{-1}$ and the efficiency of the microbial filter remains very high (e.g. Acharax fields at Hydrate Ridge; Boetius and Suess, 2004; or Pogonophora fields, HMMV; Niemann et al., 2006). However, where sulfate-depleted subsurface fluids are transported upwards at high velocity $>0.4 \mathrm{~m} \mathrm{yr}^{-1}$ AOM becomes sulfate-limited, and the efficiency of the microbial filter shrinks to $<25 \%$ (Niemann et al., 2006). Flow velocities above $2.5 \mathrm{~m} \mathrm{yr}^{-1}$ of sulfate-depleted geofluids can even prevent the flux of sulfate into the sediment and completely inhibit AOM activity (De Beer et al., 2006), with the consequence of high methane efflux to the hydrosphere.

However, some advective cold seep systems show high fluxes of both methane and sulfate. It is not well understood how sulfate is replenished in such systems. Degassing may cause an inflow of sulfate-rich bottom waters and maintain extraordinarily high AOM rates in the top 5-10 cm sediment or microbial mat. AOM reached $0.2 \mu \mathrm{mol} \mathrm{cm}^{-3} \mathrm{day}^{-1}$ at the gas bubbled shallow water seep Gullfaks ( $150 \mathrm{~m}$ water depth), and consumed about $16 \%$ of the total methane flux (Wegener et al., 2008b). The highest AOM rates measured so far are $3 \mu \mathrm{mol} \mathrm{cm}^{-3}$ day $^{-1}$ at Hydrate Ridge $(600 \mathrm{~m}$ water depth; Treude et al., 2003) and $10 \mu \mathrm{mol} \mathrm{cm}^{-3} \mathrm{day}^{-1}$ in the Black Sea microbial mats $(250 \mathrm{~m}$ water depth; Treude et al., 2007). The efficiency of the microbial filter in these $\mathrm{AOM}$ hot spots is currently not known.

The most significant problem in constraining budgets of methane emission at active cold seeps is the lack of quantitative in situ methods to measure gaseous and dissolved methane emission to the hydrosphere, as well as subsurface transport processes of methane and sulfate. It is not possible to obtain accurate measurements of methane and sulfate concentrations in interstitial porewaters of gassy sediment cores, which degas substantially during retrieval from the seafloor (De Beer et al., 2006). In addition, cold seeps show an extreme spatial and temporal variation in gas ebullition and fluid flow which is difficult to record (Tryon et al., 2002; Sauter et al., 2006). Finally, it is not known how the slow growing methanotrophs respond to variations in methane and sulfate supply.

We carried out continuous flow-through incubation of sediments from different cold seep ecosystems to test the response of ANME communities to short-term (2-40 days) variations in methane and sulfate fluxes. Flow-through reactors have been used previously for the study of growth patterns of ANME communities (Girguis et al., 2003, 2005). Our main questions were (1) How does the availability of methane and sulfate influence AOM, (2) Does the community retain its activity after starvation periods and (3) What is the efficiency of the ANME communities at high fluid flow velocities when neither methane nor sulfate are limiting.

\section{Material and methods}

Sediments from the Gullfaks (Heincke seep area; Hovland, $2007)$ in the northern North Sea $\left(61^{\circ} 10.44^{\prime} \mathrm{N}, 2^{\circ} 14.65^{\prime} \mathrm{E}\right.$, $150 \mathrm{~m}$ water depth) were sampled on Heincke cruise 208 in May 2004 using a TV-guided multiple corer. The sandy sediments were widely covered with mats of sulfide oxidizing bacteria, which marked the area of methane-based sulfide production below the mats. The recovered sediments were highly permeable and consisted of medium to coarse sands. For the incubations we sampled the blackish sediment horizon between 2 and $15 \mathrm{~cm}$, omitting the oxic top layer. Methane consumption rates, measured in in vitro incubations (using ${ }^{14} \mathrm{C}$-labeled methane according to Krüger et al., 2005), were on average $0.15 \mu \mathrm{mol} \mathrm{g}^{-1} \mathrm{day}^{-1}$. Molecular analyses showed that the methanotrophic community was dominated by consortia of ANME-2a and $-2 \mathrm{c}$ and their sulfate reducing partner bacteria of the Desulfosarciana/ Desulfococcus cluster (Wegener et al., 2008b).

Hydrate Ridge sediment $\left(44^{\circ} 34.20^{\prime} \mathrm{N}, 125^{\circ} 08.77^{\prime} \mathrm{W}\right.$; $776 \mathrm{~m}$ water depth) was retrieved during RV Sonne cruise SO165-2 in 2002 via TV MUC sampling. Samples were obtained from seafloor covered with Beggiatoa indicating a high flux of sulfide from AOM (Treude et al., 2003).

Black Sea sediment was obtained from the Dniepr basin $\left(44^{\circ} 46.41^{\prime} \mathrm{N}, 31^{\circ} 58.20^{\prime} \mathrm{E}, 326 \mathrm{~m}\right.$ water depth) during $\mathrm{R} / \mathrm{V}$ Poseidon cruise $317 / 3$ in 2004 by pushcoring with the submersible JAGO. Samples were taken from the direct vicinity of a methane seep; degassing of methane during recovery and authigenic carbonate precipitates indicated a high AOM activity in the recovered sediments (Treude et al., 2005).

After recovery, all sediments were immediately transferred to gas-tight Duran bottles and supplied with sulfate reducer medium (Widdel and Bak, 1992) as well as a methane headspace. Seawater medium was repeatedly replaced with new medium when sulfide concentrations exceeded $20 \mathrm{mM}$. All further handling of sediment was performed in an anaerobic glove box. 


\subsection{The flow-through setup}

Sediments were filled into glass columns onto glass frits (Ochs Glasgerätebau, Bovenden, Germany) (Fig. 1). In the first setup, columns with a diameter of $40 \mathrm{~mm}$ were filled with sediments from Gullfaks to a height of $120 \mathrm{~mm}$ (total volume $151 \mathrm{ml}$, ca. 250 gram dry weight $(\mathrm{gdw}))$. In the second setup (Exp. 1b), columns with a diameter of $40 \mathrm{~mm}$ were filled with different sediments to a height of $50 \mathrm{~mm}$ (total volume $63 \mathrm{ml}$ ), including inoculates from Gullfaks (sandy sediments, $95 \mathrm{gdw}$ ), Black Sea and Hydrate Ridge (clay sediments, $25 \mathrm{gdw}$ ). All concentrations and rates were normalized to dry weight of sediment.

The columns were closed with $2.5 \mathrm{~cm}$ thick butyl rubber stoppers and GL45 screw caps. Medical needles and tubing with lowest gas transmissibility (Viton ${ }^{\circledR}$; DuPont Performance Elastomers, Willmington, US) connected the columns with the reservoir of $2 \mathrm{~L}(1 \mathrm{~L}$ in the short column experiment setup) artificial sea water medium. Oxygen transmissibility of the tubing was qualitatively tested with Resazurin $\left(\mathrm{C}_{12} \mathrm{H}_{6} \mathrm{NO}_{4} \mathrm{Na}, 1 \mathrm{mg} / \mathrm{L}\right)$ labeled seawater media and was not visible. The setup was operated as a closed system with medium recycling through a large reservoir. A high-precision peristaltic pump (IP-N ${ }^{\circledR}$, Ismatec SA, Glattbrugg, Switzerland) circulated the seawater media between the reservoir and the sediment column. In all experiments a flow rate of $0.025 \mathrm{ml} \mathrm{min}^{-1}\left(36 \mathrm{ml} \mathrm{d}^{-1}\right)$ was adjusted to reach the high end of fluid flow velocities at cold seeps, and to avoid the formation of methane and sulfide gradients in the columns. Methane concentration was adjusted via pressurization of the reservoir headspace (1.5 atm $2 \mathrm{mmol} \mathrm{L}^{-1} \mathrm{CH}_{4}$ dissolved). Methane was of a $99.5 \%$ purity (Linde methane 2.5 ) and contained $<500 \mathrm{ppmv} \mathrm{H}_{2}$, and $<3000 \mathrm{ppmv}$ of other hydrocarbons. Sulfate concentration was kept at $28 \mathrm{mM}$ in the reservoir medium. All experiments were conducted at temperature of 4 to $6^{\circ} \mathrm{C}$ (Table 1 ).

\subsection{Experimental procedure}

The filled flow-through cells were mounted into the tubing system and sediment was allowed to settle for two days. The sediments were then percolated for at least 20 days with methane saturated media before starting the measurements (Table 1). Samples were taken directly from in- and outflow of the columns to determine concentrations of methane and sulfide. Sulfide concentrations were determined by the copper sulfate method (Cord-Ruwisch, 1985). Briefly, $0.1 \mathrm{ml}$ of the aliquot was added to $4 \mathrm{ml}$ copper sulfate solution $(5 \mathrm{mmol}$ $\mathrm{CuSO}_{4}$ in $\left.0.05 \mathrm{~N} \mathrm{HCl}\right)$. The liquid's absorption of monochromatic light (wavelength of $480 \mathrm{~nm}$ ) was measured immediately on a spectrometer. Absolute concentrations were determined by the calibration with sulfide standard solutions and blanks. Three replicate measurements were performed for each sample. A precision of 5\% was reported for the copper sulfide method (Cord-Ruwisch, 1985), however, in our

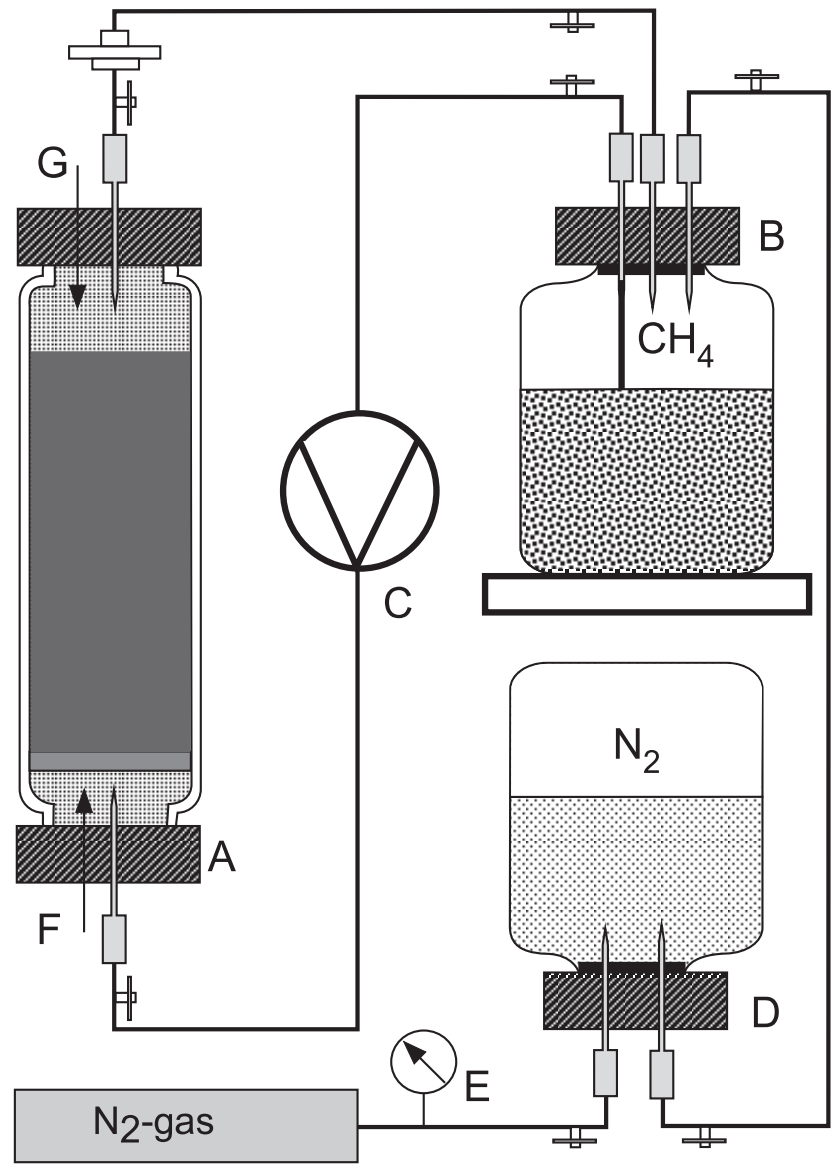

Fig. 1. Flow-through system with the sediment column (A), medium reservoir with methane: $\mathrm{CO}_{2}$ headspace (96:4) (B) and the peristaltic pump (C). System pressure is stabilized via a second medium reservoir (D) which is pressurized by nitrogen $(1.5 \mathrm{~atm})$ (E). The medium was sampled at the inflow (F) and outflow (G).

system sometimes the turbidity at the outlet caused a higher error.

Sulfide production rates (SPR) per gdw are calculated according to Eq. 1,

$\mathrm{SPR}=\left(\mathrm{H}_{2} \mathrm{~S}_{\text {out }}-\mathrm{H}_{2} \mathrm{~S}_{\text {in }}\right) \times \frac{\mathrm{F}_{\text {day }}}{\mathrm{dw}}\left[\mu \mathrm{mol} \mathrm{gdw}^{-1} \mathrm{~d}^{-1}\right]$

with the concentrations of $\mathrm{H}_{2} \mathrm{~S}(\mu \mathrm{M})$ in the out- and inflow, the volume of percolated media per day $\left(\mathrm{ml} \mathrm{day}^{-1}, \mathrm{~F}_{\text {day }}\right)$ and the dry weight $(\mathrm{gdw})$. In all experiments we observed a consistent offset between sulfide production and methane oxidation in the presence of methane, due to background sulfate reduction by other electron donors in the sediments and in the gas (see results).

For methane concentrations, subsamples of $0.5 \mathrm{ml}$ media were added into gas tight $6 \mathrm{ml}$ exetainers filled with $0.5 \mathrm{ml} \mathrm{NaOH}$. Methane concentrations were determined from the $100 \mu$ l headspace triplicates using a GC-FID (Hewlett Packard 5890A, equipped with Porapak-Q column, 
Table 1. Experimental settings.

\begin{tabular}{|c|c|c|c|c|}
\hline & $\begin{array}{l}\text { Experiment } 1 \mathrm{a}, \mathrm{b} \\
\text { Long-term, long } \\
\text { and short column }\end{array}$ & $\begin{array}{l}\text { Experiment } 2 \\
\text { Methane pulse }\end{array}$ & $\begin{array}{l}\text { Experiment } 3 \\
\text { Methane-gradient }\end{array}$ & $\begin{array}{l}\text { Experiment } 4 \\
\text { Sulfate-gradient }\end{array}$ \\
\hline $\begin{array}{l}\text { Sediments } \\
\text { Temperature } \\
\text { Flow rate }\end{array}$ & GF, HR, BS & GF & $\begin{array}{l}\mathrm{GF} \\
\quad 4^{\circ} \mathrm{C} \\
25 \mathrm{ml} \mathrm{min}^{-1}\end{array}$ & GF \\
\hline Flow velocity & $\begin{array}{l}9.1 \mathrm{~cm} \mathrm{~d}^{-1}(\mathrm{GF}) \\
4 \mathrm{~cm} \mathrm{~d}^{-1}(\mathrm{HR}, \mathrm{BS})\end{array}$ & $9.1 \mathrm{~cm} \mathrm{~d}^{-1}$ & $9.1 \mathrm{~cm} \mathrm{~d}^{-1}$ & $9.1 \mathrm{~cm} \mathrm{~d}^{-1}$ \\
\hline columns & long + short & long & long & long \\
\hline $\mathrm{SO}_{4}^{2-}$-conc. & $28 \mathrm{mM}$ & $28 \mathrm{mM}$ & $28 \mathrm{mM}$ & $1,2,3,28 \mathrm{mM}$ \\
\hline $\begin{array}{l}\mathrm{CH}_{4} \text {-conc. } \\
\text { Sampling period }\end{array}$ & $\begin{array}{l}1.5 \text { atm } \\
\text { Long columns: } \\
\text { every } 6 \text { to } 12 \text { days } \\
\text { over } 85 \text { days; } \\
\text { short columns every } \\
6 \text { to } 20 \text { days } \\
\text { over } 160 \text { days }\end{array}$ & $\begin{array}{l}1.5 \text { atm } \\
\text { every } \sim 6 \text { days; } \\
\text { daily at the } \\
\text { beginning and } \\
\text { end of methane } \\
\text { pulse over } 12 \text { days }\end{array}$ & $\begin{array}{l}0,0.015,0.25,0.41 .01 .5 \mathrm{~atm} \\
\text { every } 2 \text { to } 3 \text { days } \\
\text { over } 10 \text { days for } \\
\text { each condition } 8 \\
\text { to } 12 \text { days } \\
\text { equilibration } \\
\text { phase }\end{array}$ & $\begin{array}{l}1.5 \mathrm{~atm} \\
\text { after equilibration } \\
\text { every } 3 \text { days over } \\
12 \text { days }\end{array}$ \\
\hline
\end{tabular}

Table 2. Summary of the main characteristics of the sampled seep sites. Rate measurements were derived from radiotracer studies (referenced) and column incubations (this study) n.d.=not determined.

\begin{tabular}{|c|c|c|c|c|c|c|}
\hline & \multicolumn{2}{|c|}{ Black Sea } & \multicolumn{2}{|c|}{ Hydrate Ridge } & \multicolumn{2}{|c|}{ Gullfaks } \\
\hline $\begin{array}{l}\text { Sample } \\
\text { environment }\end{array}$ & \multicolumn{2}{|c|}{$\begin{array}{l}\text { Sediment next to } \\
\text { microbial chimneys }\end{array}$} & \multicolumn{2}{|c|}{ Beggiatoa covered area } & \multicolumn{2}{|c|}{$\begin{array}{l}\text { Beggiatoa mat } \\
\text { covered area }\end{array}$} \\
\hline In situ temperature & $8^{\circ} \mathrm{C}$ & $4^{\circ} \mathrm{C}$ & $4^{\circ} \mathrm{C}$ & $4^{\circ} \mathrm{C}$ & $8^{\circ} \mathrm{C}$ & $4^{\circ} \mathrm{C}$ \\
\hline $\begin{array}{l}\text { AOM rate } \\
\left(\mu \mathrm{mol} \mathrm{gdw} \mathrm{dw}^{-1} \mathrm{~d}^{-1}\right)\end{array}$ & n. d. & $0.42 \pm 0.15$ & $0.05-1^{\mathrm{a}}$ & $0.34 \pm 0.15$ & $0.01-0.18^{\mathrm{b}}$ & $\begin{array}{l}0.08 \pm 0.03^{c} \\
0.12 \text { to } 0.19^{d}\end{array}$ \\
\hline $\begin{array}{l}\text { SR rate } \\
\left(\mu \mathrm{molg} \mathrm{dw}{ }^{-1} \mathrm{~d}^{-1}\right)\end{array}$ & n.d. & $0.58 \pm 0.18$ & $0.3-0.6^{\mathrm{a}}$ & $0.47 \pm 0.16$ & $0.05-0.3^{b}$ & $\begin{array}{l}0.07 \pm 0.03^{\mathrm{c}} \\
0.15-0.23^{\mathrm{d}}\end{array}$ \\
\hline
\end{tabular}

${ }^{\mathrm{a}}$ Treude et al., 2003; ${ }^{\mathrm{b}}$ Wegener et al., 2008b; ${ }^{\mathrm{c}}$ short column experiment; ${ }^{\mathrm{d}}$ long column experiment

6ft, 0.125', Agilent Technologies, Sta. Clara, CA), which was calibrated with methane standards. The AOM rate is calculated according to Eq. 2

$\mathrm{AOM}=\mathrm{CH}_{4}$ in $-\mathrm{CH}_{4}$ out $\times \frac{\mathrm{F}_{\text {day }}}{\mathrm{dw}}\left[\mu \mathrm{mol} \mathrm{gdw}^{-1} \mathrm{~d}^{-1}\right]$

with the methane concentrations of the in- and the outflow $\left(\mathrm{CH}_{4 \text { in/out }}\right)$, the flow rate per day $\mathrm{F}_{\text {day }}$ as well as the dry weight gdw of the sediment in the column. Sulfate concentrations were measured using nonsuppressed ion chromatography according to Ferdelman et al. (1997).

\section{Results and discussion}

\subsection{Sulfide production and methane consumption un- der stable conditions}

The aim of the first experiment (Exp. 1) was to reach stable conditions in the two different flow-through setups with long and short columns, to obtain comparable measurements between columns and to constrain the temporal evolution of $\mathrm{AOM}$ in the incubations. In the experiment 1a using five replicate long columns, Gullfaks sediments were percolated for 120 days with constant methane concentrations of around $1.6 \mathrm{mM}$ and starting sulfide concentration of $0.5 \mathrm{mM}$ (Table 1). The flow rate was $36 \mathrm{ml} \mathrm{d}^{-1}$ in all columns which corresponds to a flow velocity of $32 \mathrm{~m} \mathrm{yr}^{-1}$ at Gullfaks (porosity $35 \%$ ) and $14 \mathrm{~m} \mathrm{yr}^{-1}$ at BS and HR (porosity $~ 80 \%$ ). The passage time for the medium entering through the bottom of the column (inflow) to the outflow was 36 hours. A fluid flow 
velocity of $30 \mathrm{~m} \mathrm{yr}^{-1}$ is at the higher end of transport rates at cold seep ecosystems and was previously observed e.g. in active settings like those above gas hydrate at stability limits (Linke et al., 1994; Torres et al., 2002; Sauter et al. 2006).

Figure 2 shows the results for a single replicate column of Gullfaks seep sediments (a summary of the results from other replicates is provided in Table 3). Both sulfide production and methane oxidation were relatively stable over 85 days. Methane oxidation was on average $0.16 \pm 0.04 \mu \mathrm{mol} \mathrm{gdw}^{-1}$. Background sulfide production from organoclastic sulfate reduction in the sediments incubated without methane was as low as $0.04 \mu \mathrm{mol} \mathrm{gdw}^{-1} \mathrm{day}^{1}$. The methane utilized in all experiments contained up to $3500 \mathrm{ppmv}$ of other potential electron donors for sulfate reduction such as $\mathrm{H}_{2}$, and higher hydrocarbons. Their oxidation could explain up to $0.012 \mu \mathrm{mol} \mathrm{gdw}^{-1} \mathrm{~d}^{-1}$ or $<8 \%$ of the total sulfide production at methane saturation. Hence, the background sulfide production from the sedimentary matter as well as from gas impurities was $10-20 \%$ of the total sulfate reduction in the experiments and explains the constant offset between sulfide production and methane consumption observed in all experiments.

As an additional independent measure, the total sulfide production of the system (Exp. 1a) was calculated from the reservoir concentration $\left[\left(\mathrm{H}_{2} \mathrm{~S}_{\text {end }}-\mathrm{H}_{2} \mathrm{~S}_{\text {start }}\right) \times\right.$ total media volume $=3.2 \mathrm{mmol}]$. This matches the decline in the integrated methane concentration $\left[\left(\mathrm{CH} 4_{\text {in }(n)}-\mathrm{CH} 4_{\text {out }(n)}\right) \times\right.$ flow rate $\times$ time $=3.0 \mathrm{mmol}$ methane oxidized], when taking into account the above described offset between sulfide production and methane oxidation.

In the short column setup (Exp. 1b, Table 3), inoculates from the Black Sea, from Hydrate Ridge and Gullfaks were tested in parallel incubations. The sulfate reduction and methane oxidation rates stayed constant for a period of 160 days. We measured average methane consumption rates of $0.42( \pm 0.15), 0.34( \pm 0.15)$ and $0.08( \pm 0.03)$ $\mu \mathrm{mol} \mathrm{gdw} \mathrm{gd}^{-1} \mathrm{~d}^{-1}$ and sulfate reduction rates of $0.58( \pm 0.18)$, $0.47( \pm 0.016)$ and $0.07( \pm 0.03) \mu \mathrm{mol} \mathrm{gdw}^{-1} \mathrm{~d}^{-1}$ for Black Sea, Hydrate Ridge and Gullfaks, respectively. The AOM rates match well with measurements on freshly sampled sediments for those sediment horizons used as inoculate in the flow through columns (Table 2).

Within the observation period, we did not observe a significant increase of metabolic activity over time, which would have indicated population growth (Nauhaus et al., 2007). We can exclude nutrient limitation in our systems since all potentially limiting trace elements were added at sufficient concentrations according to the standard recipe for the cultivation of anaerobes (Widdel and Bak, 1992). Similar observations of constant AOM rates over long incubation times were published by Girguis et al. $(2003,2005)$. In their investigation, seep sediments were percolated with methane-saturated seawater at atmospheric pressure for 24 weeks, however no growth-related increase in AOM activity was observed. Reasons for this stagnation of population size may be energy

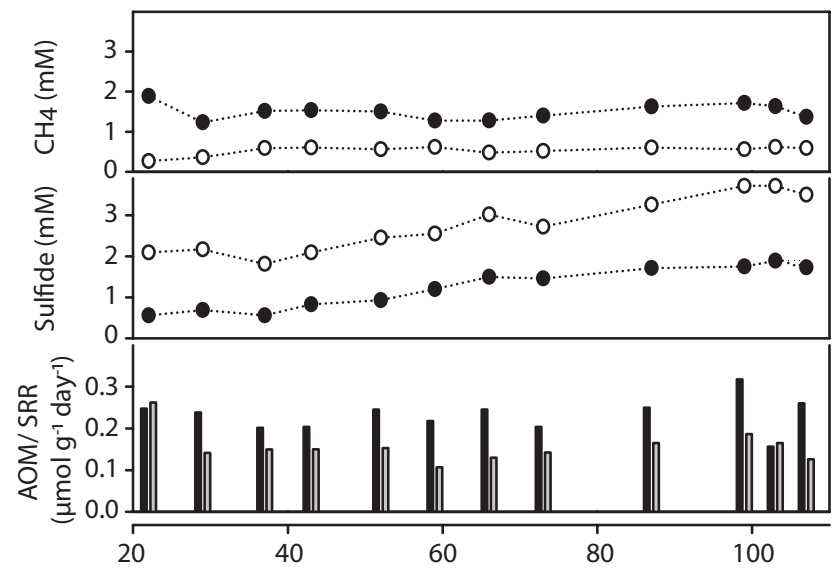

Fig. 2. Comparison of methane oxidation and sulfide production in a long-term continuous flow-through experiment (Exp. 1). The data shown are from one of five similar replicates (Gullfaks seep sediments) starting after 20 days of system equilibration (for the other replicates see Table 3). $\mathrm{T}_{(0)}: 0.5 \mathrm{mM} \mathrm{SO} 4, \mathrm{CH} 41.5 \mathrm{~atm}$. (a) The development of methane and (b) of sulfide (inflow concentration (filled circles); outflow concentrations (open circles)) (c) the calculated methane oxidation (grey bars) and sulfide production rates (black bars).

limitation by methane supply at atmospheric pressure. In high pressure batch incubations $\left(\sim 1.4 \mathrm{MPaCH}_{4}\right)$, Nauhaus et al. (2007) observed an increase in sulfide production by a factor of ten within almost two years related to growth of the ANME community (growth rate of $0.021 \mathrm{week}^{-1}$ ). It was found that the growth of anaerobic methanotrophs is extremely slow, probably with generation times of $>7$ months at atmospheric pressure (Girguis et al., 2005; Nauhaus et al., 2007).

In conclusion, we could show that flow through columns can be used as a stable set up for short (days to weeks) and long term experiments (months) for physiological experiments using seep sediments naturally enriched in ANME populations from a variety of locations with different sediment porosities.

\subsection{Reaction of SR and methane consumption to a methane pulse}

The results of a 40 days methane pulse experiment (Exp. 2) using sediments from Gullfaks are presented in Fig. 3. Parallel incubations of four other columns filled with Gullfaks sediments, gave similar results (Table 3). The columns were run for 120 days at $2 \mathrm{mM}$ methane and $28 \mathrm{mM}$ sulfate, before methane was removed for 36 days (Fig. 3a). During the 36 days starvation phase, SR dropped to rates as low as $\sim 0.04 \mu \mathrm{mol} \mathrm{gdw}^{-1} \mathrm{~d}^{-1}$ which represents the background SR fueled by sedimentary organic matter in this experiment. After 36 days of starvation, methane concentration in the medium was increased to $2 \mathrm{mM}$ within 
Table 3. Results of all replicate incubations for the methane pulse and the sulfate and methane concentration gradient experiment. C=replicate core number (rates in $\left(\mu \mathrm{mol} \mathrm{gdw} \mathrm{gd}^{-1}\right)$ ).

\begin{tabular}{lccccc}
\hline \multicolumn{5}{l}{ Exp. 1a. Summary of long-term replicate incubations of Gullfaks sediments in long columns } \\
\hline Column & C1 & C2 & C3 & C4 & C5 \\
SRR & $0.23 \pm 0.03$ & $0.18 \pm 0.06$ & $0.21 \pm 0.07$ & $0.20 \pm 0.07$ & $0.18 \pm 0.06$ \\
AOM & $0.16 \pm 0.04$ & $0.15 \pm 0.05$ & $0.16 \pm 0.05$ & $0.17 \pm 0.05$ & $0.17 \pm 0.04$
\end{tabular}

Exp. 1b. Long-term incubations in short columns

\begin{tabular}{lcccccc}
\hline & \multicolumn{2}{c}{ Black Sea } & \multicolumn{2}{c}{ Hydrate Ridge } & \multicolumn{2}{c}{ Gullfaks } \\
day & SR & AOM & SR & AOM & SR & AOM \\
5 & 0.57 & 0.46 & n.d. & n.d. & 0.03 & 0.12 \\
14 & 0.45 & 0.44 & 0.40 & 0.46 & 0.08 & 0.11 \\
19 & 0.64 & 0.49 & 0.62 & 0.29 & 0.08 & 0.06 \\
31 & 0.62 & 0.25 & 0.54 & 0.21 & 0.08 & 0.11 \\
47 & 0.66 & 0.59 & 0.49 & 0.38 & 0.06 & 0.03 \\
54 & 0.85 & 0.58 & 0.31 & 0.25 & 0.03 & 0.09 \\
70 & 0.87 & 0.35 & 0.55 & 0.36 & 0.04 & 0.11 \\
76 & 0.42 & 0.12 & n.d. & n.d. & 0.05 & 0.08 \\
86 & 0.38 & 0.60 & n.d. & n.d. & 0.09 & 0.10 \\
95 & 0.37 & 0.42 & 0.26 & 0.55 & 0.09 & 0.11 \\
116 & 0.54 & 0.37 & 0.58 & 0.18 & 0.11 & 0.09 \\
123 & 0.57 & n.d. & 0.50 & 0.49 & 0.09 & 0.09 \\
130 & 0.33 & n.d. & 0.56 & 0.38 & 0.09 & 0.06 \\
137 & 0.48 & 0.41 & 0.20 & 0.28 & 0.10 & 0.07 \\
143 & 0.82 & 0.65 & 0.70 & 0.49 & 0.04 & 0.05 \\
150 & 0.46 & 0.21 & 0.62 & 0.26 & 0.07 & 0.02 \\
163 & 0.80 & 0.32 & 0.31 & 0.33 & 0.10 & 0.06
\end{tabular}

Exp. 2. Methane pulse experiment

\begin{tabular}{|c|c|c|c|c|c|}
\hline & $\mathrm{C} 1$ & $\mathrm{C} 2$ & C3 & $\mathrm{C} 4$ & $\mathrm{C} 5$ \\
\hline $\mathrm{SR}\left(\mathrm{w} / \mathrm{o} \mathrm{CH}_{4}\right)$ & $0.06 \pm 0.01$ & $0.04 \pm 0.03$ & $0.01 \pm 0.01$ & $0.03 \pm 0.03$ & $0.02 \pm 0.02$ \\
\hline $\mathrm{SR}\left(+\mathrm{CH}_{4}\right)$ & $0.23 \pm 0.06$ & $0.16 \pm 0.06$ & $0.17 \pm 0.08$ & $0.19 \pm 0.07$ & $0.15 \pm 0.07$ \\
\hline $\mathrm{AOM}\left(+\mathrm{CH}_{4}\right)$ & $0.19 \pm 0.03$ & $0.15 \pm 0.04$ & $0.13 \pm 0.02$ & $0.15 \pm 0.04$ & $0.12 \pm 0.02$ \\
\hline
\end{tabular}

Exp. 3. Methane concentration gradient

\begin{tabular}{lccccc}
\hline & \multicolumn{2}{c}{$\mathrm{C} 2$} & & \multicolumn{2}{c}{$\mathrm{C} 3$} \\
$\mathrm{CH}_{4}(\mathrm{mM})$ & $\mathrm{SR}$ & $\mathrm{AOM}$ & $\mathrm{CH}_{4}(\mathrm{mM})$ & $\mathrm{SR}$ & $\mathrm{AOM}$ \\
0.05 & $0.02 \pm 0.01$ & - & 0.01 & $0.02 \pm 0.01$ & - \\
0.33 & $0.07 \pm 0.02$ & $0.01 \pm 0.01$ & 0.29 & $0.07 \pm 0.01$ & $0.01 \pm 0.00$ \\
0.47 & $0.15 \pm 0.01$ & $0.03 \pm 0.01$ & 0.5 & $0.12 \pm 0.02$ & $0.03 \pm 0.01$ \\
0.78 & $0.15 \pm 0.03$ & $0.05 \pm 0.02$ & 0.73 & $0.16 \pm 0.03$ & $0.04 \pm 0.02$ \\
1.34 & $0.20 \pm 0.03$ & $0.11 \pm 0.03$ & 1.24 & $0.17 \pm 0.02$ & $0.09 \pm 0.01$ \\
2.28 & $0.23 \pm 0.08$ & $0.18 \pm 0.08$ & 2.26 & $0.21 \pm 0.04$ & $0.18 \pm 0.07$
\end{tabular}

Exp. 4. Sulfate concentration gradient

\begin{tabular}{lccccc}
\hline & \multicolumn{2}{c}{$\mathrm{C} 4$} & & \multicolumn{2}{c}{$\mathrm{C} 5$} \\
$\mathrm{SO}_{4}^{2-}(\mathrm{mM})$ & $\mathrm{SR}$ & $\mathrm{AOM}$ & $\mathrm{SO}_{4}^{2-}(\mathrm{mM})$ & $\mathrm{SR}$ & $\mathrm{AOM}$ \\
0.96 & $0.10 \pm 0.03$ & $0.08 \pm 0.02$ & 0.98 & $0.11 \pm 0.03$ & $0.07 \pm 0.01$ \\
1.92 & $0.14 \pm 0.03$ & $0.11 \pm 0.02$ & 1.94 & $0.16 \pm 0.02$ & $0.09 \pm 0.02$ \\
2.99 & $0.18 \pm 0.07$ & $0.10 \pm 0.03$ & 2.88 & $0.15 \pm 0.03$ & $0.10 \pm 0.02$ \\
28 & $0.23 \pm 0.06$ & $0.18 \pm 0.06$ & 28 & $0.21 \pm 0.04$ & $0.16 \pm 0.06$ \\
\hline
\end{tabular}


2 days. The outflow showed increasing sulfide concentrations immediately after methane was percolated through the column (day 38, Fig. 3b). Accordingly, AOM (Fig. 3c) and SR (Fig. 3d) returned to similar rates as before the starvation phase $\left(0.19 \pm 0.03 \mu \mathrm{mol} \mathrm{gdw}^{-1} \mathrm{~d}^{-1}\right.$ and $0.24 \pm 0.05 \mu \mathrm{mol} \mathrm{gdw}^{-1} \mathrm{~d}^{-1}$, respectively). After 40 days of exposure to methane, the medium was again degassed. Within 6 days, the methane concentration in the outflow fell below $50 \mu \mathrm{M}$ and both methane oxidation and sulfate reduction rates decreased almost completely to zero. This proves the direct coupling between methane oxidation and sulfide production in AOM. However, it remains unknown whether the electron transfer from methane to sulfide is carried out within one or between two organisms.

Previous investigations found that anaerobic methanotrophs produce large amounts of methyl-coenzyme $\mathrm{M}$ reductase (MCR), which is most likely the enzyme responsible for the first step in methane oxidation. For example, MCR constituted $7 \%$ of the total environmental protein extracted from methanotrophic mats of the Black Sea (Krüger et al., 2003). It may be a good strategy to maintain a large amount of functional proteins in the extremely slow growing cells, to utilize a wide range of methane concentrations. For example, in our experiment, the present methanotrophic population utilized the same fraction of methane without any delay, within a range in substrate availability of 2 orders of magnitude.

Furthermore, the results of the methane pulse experiment support previous observations on the longevity of seep methanotrophs kept under anoxic conditions at in situ temperature without substrate. Even after storage of months to years, immediate sulfide formation by the methanotrophic populations can be observed directly after methane addition, reaching similar rates as in the field, at the time of sampling. The ability of anaerobic methanotrophs to survive long starvation periods could be an important advantage, especially with regard to the high spatial and temporal variability of methane fluxes at seeps, and also when considering their slow growth.

\subsection{Sulfate reduction and methane oxidation at differ- ent methane and sulfate concentrations}

At the low energy yield of AOM, efficient use of the natural range of methane and sulfate concentrations is critical to the anaerobic methanotrophs. In nature, AOM is often limited to a narrow zone of $\mathrm{mm}$ to decimeters where methane and sulfate overlap (SMTZ) with usually low concentrations of both reactants. Previous environmental observations suggested a strong dependence of AOM rates on the fluxes of sulfate (Treude et al., 2003). At seeps, methane concentrations and fluxes may be extremely high, but very often sulfate is depleted within the top few $\mathrm{cm}$, and its penetration from the overlying bottom water can be suppressed by high upward fluxes of sulfate free subsurface fluids (Niemann et
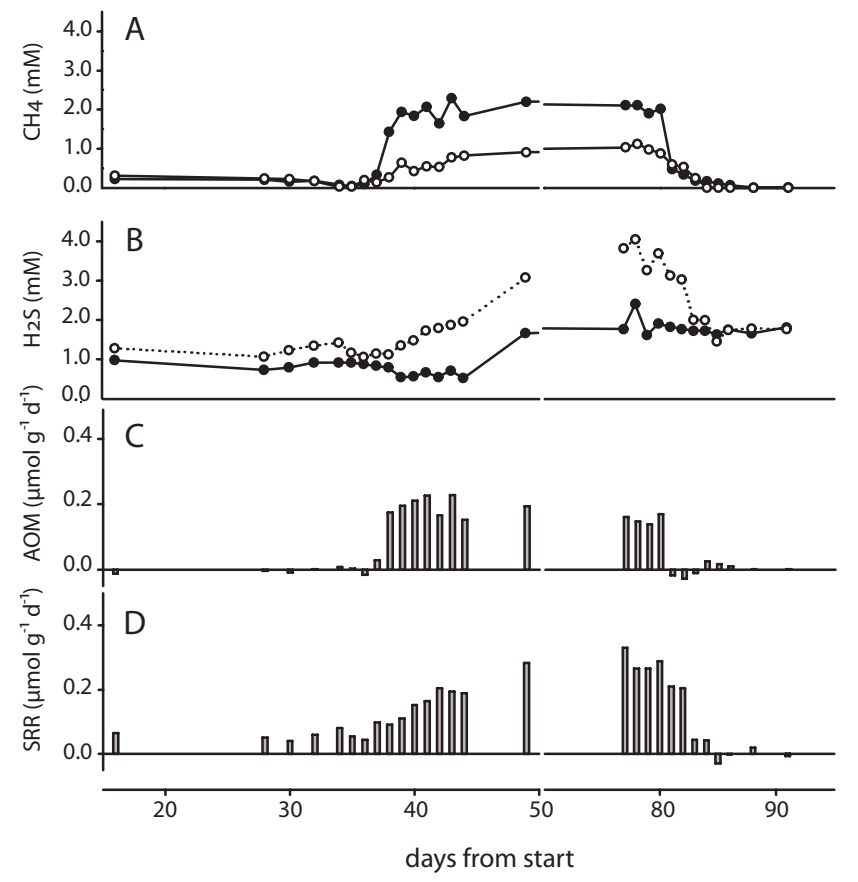

Fig. 3. Changing activities of a methanotrophic community in response to a methane pulse (Exp. 2, C1). (a) Methane concentrations, (b) sulfide concentrations. Filled circles represent the measurements at the inflow and open circles those at the outflow; (c) the resulting methane oxidation rates and (d) sulfide production.

al., 2006). Here we investigated a third situation prevailing at seeps with strong degassing and advective flow of sulfate into the methane rich sediment horizons. To examine the effect of AOM reactant availability, we incubated two replicate columns from Gullfaks with a series of different methane and sulfate concentrations. After an equilibration time of 8 to 12 days at each concentration, three to five measurements of methane and sulfide concentrations were performed (Table 2). Figures 4 and 5 show AOM and SR rates at different concentrations of methane and sulfate and constant flow velocities of $30 \mathrm{~m} \mathrm{yr}^{-1}$.

In Exp. 3 the metabolic activities without methane and at different methane concentrations between 0.3 and $2.3 \mathrm{mM}$ were examined (Fig. 4, Table 3). In the absence of methane, a background sulfide production of about $0.02 \pm 0.01 \mu \mathrm{mol} \mathrm{gdw}^{-1} \mathrm{~d}^{-1}$ was determined. Sulfide production increased to $0.17 \mu \mathrm{mol} \mathrm{gdw}^{-1} \mathrm{~d}^{-1}$ at $1.35 \mathrm{mMCH}_{4}$ and to $0.21 \mu \mathrm{mol} \mathrm{gdw}^{-1} \mathrm{day}^{-1}$ at $2.3 \mathrm{mM} \mathrm{CH}_{4}$. Methane oxidation followed the trend of sulfide production with rates of $0.02,0.10$ and $0.17 \mu \mathrm{mol} \mathrm{gdw}^{-1} \mathrm{~d}^{-1}$ at $0.33 \mathrm{mM}$, $1.35 \mathrm{mM}$ and $2.3 \mathrm{mM} \mathrm{CH}_{4}$, respectively (Table 3 ). The high excess of sulfide production (up to the double of methane consumption) in this experiment is most likely due to contamination with alternative organic electron acceptors for sulfate reduction (acetate etc.) after medium exchange. However, this contamination may not affect the methane 


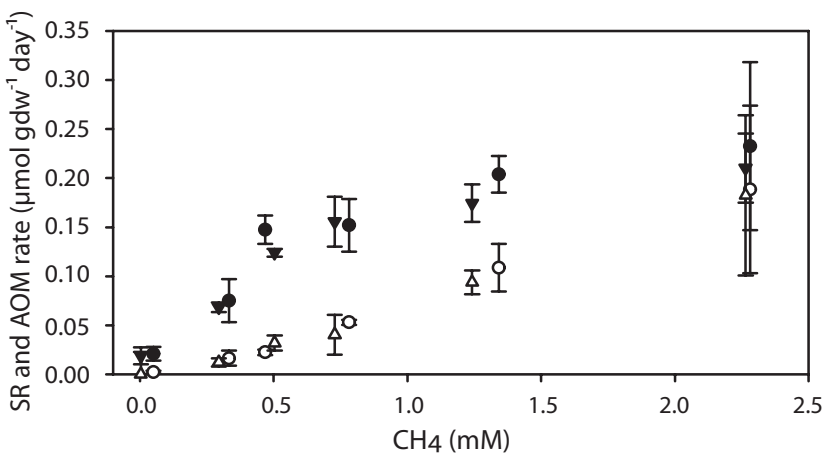

Fig. 4. Effect of different methane concentrations (Exp. 3) on rates of methane oxidation (open symbols) and sulfate reduction (filled symbols). Data are shown for two replicate columns marked as circles $(\mathrm{C} 1)$ and triangles $(\mathrm{C} 2)$.

budgets, which show linear relation between methane concentration and methane consumption in the whole tested methane range. This indicates that substrate saturation of the metabolic activity was not reached. Hence we conclude that the apparent $\mathrm{K}_{M}$-value for methane in AOM is above the tested range, i.e. $>2 \mathrm{mM}$. This is in agreement with Nauhaus et al. (2002), who observed a linear relationship between methane oxidation and sulfide production at methane pressures below $0.1 \mathrm{MPa}$ (about $1.5 \mathrm{mM}$ ), and suggested a high methane $\mathrm{K}_{M}$ in the range of several mM for AOM and methane-fueled SR. In comparison, for hydrogenotrophic sulfate reduction, half saturation constants for $\mathrm{H}_{2}$ are as low as $141 \mathrm{~Pa}(\sim 1 \mu \mathrm{mol}$; Lovley et al., 1982), but the energy yield of this process is orders of magnitudes higher than in AOM. The high half saturation constant for methane in AOM may be due to the reverse operation of the methanogenic methyl-coenzyme $M$ reductase which would produce a methyl radical as a first step in AOM (Krüger et al., 2003; Hallam et al., 2004; Shima and Thauer, 2005).

The influence of sulfate concentration on the oxidation of methane was examined by percolating two other replicate columns with reduced seawater medium containing 28 , 3, 2 and $1 \mathrm{mM}$ sulfate (Exp. 4; Fig. 5). Within the tested low sulfate concentrations from 3 to $1 \mathrm{mM}$ a weak decline of metabolic rates was determined (Table 3). However the scattering within the data was quite strong. We suggest that the half-saturation for sulfate in methanotrophy is below the examined concentrations, probably around $500 \mu \mathrm{M}$. In comparison, organoclastic sulfate reducers show halfsaturation constants between $70 \mu \mathrm{M}$ (Desulfovibrio salexigens) and $200 \mu \mathrm{M}$ (Desulfobacter postgatei) (Ingvorsen and Jørgensen, 1984; Ingvorsen et al., 1984). In flow-through incubations of undisturbed marine sediments Pallud and Van Capellen (2006) found $\mathrm{k}_{M}$-values 100 to $300 \mu \mathrm{M}$. These $\mathrm{k}_{M}$-values were significantly lower than results from simultaneously performed batch incubations (up to $1620 \mu \mathrm{M}$; Boudreau and Westrich, 1984). Sulfate reducers have

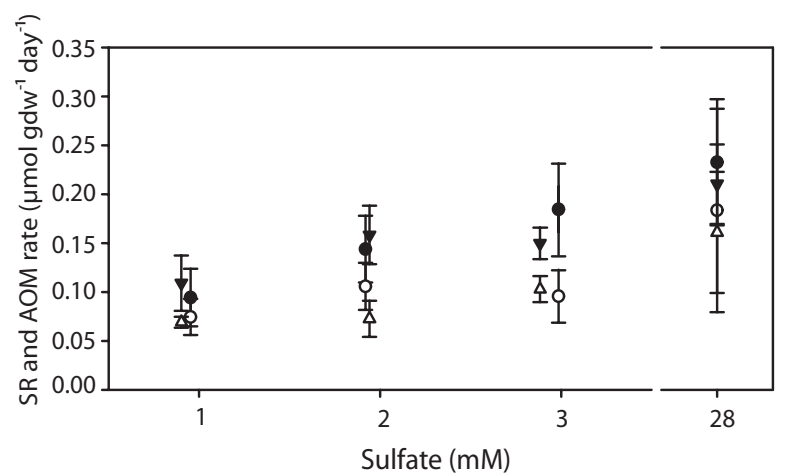

Fig. 5. Effect of different sulfate concentrations (Exp. 4) on rates of methane oxidation (open symbols) and sulfide production (filled symbols). Data are shown for two replicate columns marked as circles $(\mathrm{C} 1)$ and triangles $(\mathrm{C} 2)$.

different strategies to achieve low $\mathrm{k}_{M}$-values; e.g. Desulfovibrio desulfuricans shows intracellular sulfate enrichment up to the factor of 5000 compared to its environment (Cypionka, 1989). Compared to the organoclastic sulfate reducers, the organism performing sulfate reduction in anaerobic methanotrophy investigated here appear to have a relatively high $\mathrm{k}_{M}$ for sulfate, at the low end of the $\mathrm{mM}$ range. This might be due to the low energy yield of methane dependent sulfate reduction, which may limit energy intense metabolic adaptations such as sulfate enrichment by the organisms. It remains unknown if the methanotrophic populations of the ubiquitous sulfate methane transition zones in the seabed are better adapted to low sulfate concentrations than their relatives inhabiting the cold seeps. Further experiments with ANME-enrichments in high-pressure flow-through systems are needed for the determination of half saturation constants of sulfate and methane in AOM.

\section{Conclusions}

At a constant methane supply of about $2 \mathrm{mM}$, different marine methanotrophic communities enclosed in continuous flow through columns resulted in a stable rate of anaerobic oxidation of methane over 160 days. A tight link between methane oxidation and sulfate reduction was clearly shown by providing pulses of methane to environmental methanotrophic communities. An interruption of the methane supply led to an immediate decline of sulfate reduction. After percolation with methane free media for more than 40 days, former methane oxidation and sulfate reduction rates were reached immediately without a lag phase. Hence, the methanotrophic populations seem to be able to survive relatively long starving periods. Rates of anaerobic oxidation of methane were strongly regulated by methane concentrations. Between 0.3 and $2.3 \mathrm{mM} \mathrm{CH}_{4}$ we found an almost linear increase of methane oxidation and sulfide production. 
This suggests half-saturations ( $\mathrm{k}_{M}$-values) for methane of several $\mathrm{mM}$ in AOM. Sulfate concentrations below $3 \mathrm{mM}$ caused a decrease in methane oxidation rates, suggesting that the apparent $\mathrm{k}_{M}$ for sulfate is at the lower end of the $\mathrm{mM}$ range. Apparently, the high level of functional proteins maintained by the anaerobic methanotrophs allows for immediate responses to a wide range of concentrations of both electron donor and acceptor in the anaerobic oxidation of methane.

Acknowledgements. We thank Tim Ferdelman for helpful discussions and corrections of a first version of the manuscript. This publication is a contribution to the MARUM project "Seepage of Fluid and Gas".

The service charges for this open access publication have been covered by the Max Planck Society.

Edited by: S. W. A. Naqvi

\section{References}

Boetius, A. and Suess, E.: Hydrate Ridge: a natural laboratory for the study of microbial life fueled by methane from near-surface gas hydrates, Chem. Geol., 205, 291-310, 2004.

Boetius, A. Ravenschlag, K., Schubert, C. J., Rickert, D., Widdel, F., Gieseke, A., Amann, R., Jørgensen, B. B., Witte, U., and Pfannkuche, O.: A marine microbial consortium apparently mediating anaerobic oxidation of methane, Nature, 407, 623-626, 2000.

Boudreau, B. P. and Westrich, J. T.: The dependence of bacterial sulfate reduction on sulfate concentration in marine sediments, Geochim. Cosmochim. Ac., 48, 2503-2516, 1984.

Canfield, D.: Organic matter oxidation in marine sediments. Interactions of $\mathrm{C}, \mathrm{N}, \mathrm{P}$ and $\mathrm{S}$ biogeochemical cycles and global change, NATO ASI Series, 14, 33-363, 1993.

Canfield, D., Kristensen, E., and Thamdrup, B.: Aquatic Geomicrobiology. San Diego, California, Elsevier, 656 pp., 2005.

Cord-Ruwisch, R.: A quick method for the determination of dissolved and precipitated sulfides in cultures of sulfate-reducing bacteria, J. Microbiol. Meth., 4(1), 33-36, 1985.

Cypionka, H.: Characterization of sulfate transport in Desulfovibrio desulfuricans, Arch. Microbiol., 152(3), 237-243, 1989.

De Beer, D., Sauter, E., Niemann, H., Kaul, N., Foucher, J., Witte, U., Schlüter, M., and Boetius, A.: In situ fluxes and zonation of microbial activity in surface sediments of the Håkon Mosby Mud Volcano, Limnol. Oceanogr., 51, 1315-1331, 2006.

Ferdelman, T. G., Lee, C., Pantoja, S., Harder, J., Bebout, B. M., and Fossing, H.: Sulfate reduction and methanogenesis in a Thioploca-dominated sediment off the coast of Chile, Geochim. Cosmochim. Ac., 61(15), 3065-3079, 1997.

Girguis, P. R., Cozen, A. E., and DeLong, E. F.: Growth and population dynamics of anaerobic methane-oxidizing archaea and sulfate-reducing bacteria in a continuous-flow bioreactor, Appl. Environ. Microb., 71(7), 3725-3733, 2005.

Girguis, P. R., Orphan, V., Hallam, S., and DeLong, E. F.: Growth and methane oxidation rates of anaerobic methanotrophic archaea in a continuous-flow bioreactor, Appl. Environ. Microb., 69(9), 5472-5482, 2003.
Hallam, S. J., Putnam, N., Preston, C. M., Detter, J. C., Rokhsar, D., Richardson, P. M., and DeLong, E. F.: Reverse methanogenesis: Testing the hypothesis with environmental genomics, Science, 305(5689), 1457-1462, 2004.

Hanson, R. S. and Hanson, T. E.: Methanotrophic bacteria, Microbiol. Rev., 60, 439-471, 1996.

Hovland, M.: Discovery of prolific natural methane seeps at Gullfaks, northern North Sea, Geo-Mar. Lett., 27, 197-201, 2007.

Ingvorsen, K. and Jørgensen, B. B.: Kinetics of sulfate uptake by freshwater and marine species of Desulfovibrio, Arch. Microbiol., 139, 61-66, 1984.

Ingvorsen, K., Zehnder, A. J. B., and Jørgensen, B. B.: Kinetics of sulfate and acetate uptake by Desulfobacter postgatei, Appl. Environ. Microb., 47, 403-408, 1984.

Joye, S. B., Boetius, A., Orcutt, B. N., Montoya, J. P., Schulz, H. N., Erickson, M. J., and Lugo, S. K.: The anaerobic oxidation of methane and sulfate reduction in sediments from Gulf of Mexico cold seeps, Chem. Geol., 205, 219-238, 2004.

Krüger, M., Meyerdieks, A., Glöckner, F. O., Amann, R., Widdel, F., Kube, M., Reinhardt, R., Kahnt, J., Böcher, R., Thauer, R. K., and Shima, S.: A conspicuous nickel protein in microbial mats that oxidize methane anaerobically, Nature, 426, 878-881, 2003.

Krüger, M., Treude, T., Wolters, H., Nauhaus, K., and Boetius, A.: Microbial methane turnover in different marine habitats, Palaeogeogr. Palaeocl., 227(1-3), 6-17, 2005.

Linke, P., Suess, E., Torres, M., Martens, V., Rugh, W. D., Ziebis, W., and Kulm, L. D.: In situ measurement of fluid flow from cold seeps at active continental margins, Deep-Sea Res., 41, 721-739, 1994.

Lovley, D. R., Dwyer, D. F., and Klug, M. J.: Kinetic analysis of competition between sulfate reducers and methanogens for hydrogen in sediments, Appl. Environ. Microbiol., 43(6), 13791379, 1982.

Meyerdierks, A., Kube, M., Lombardot, T., Knittel, K., Bauer, M., Glöckner, F. O., Reinhardt, R., and Amann, R.: Insights into the genomes of archaea mediating the anaerobic oxidation of methane, Environ. Microbiol., 7, 1937-1951, 2005.

Milkov, A. V.: Global estimates of hydrate-bound gas in marine sediments: how much is really out there?, Earth-Sci. Rev., 66(34), 183-197, 2004.

Nauhaus, K., Albrecht, M., Elvert, M., Boetius, A. and Widdel, F.: In vitro cell growth of marine archaeal-bacterial consortia during anaerobic oxidation of methane with sulfate, Environ. Microbiol., 9(1), 187-196, 2007.

Nauhaus, K., Boetius, A., Krüger, M., and Widdel, F.: In vitro demonstration of anaerobic oxidation of methane coupled to sulphate reduction in sediments from a marine gas hydrate area, Environ. Microbiol., 4(5), 296-305, 2002.

Nauhaus, K., Treude, T., Boetius, A., and Kruger, M.: Environmental regulation of the anaerobic oxidation of methane: a comparison of ANME-I and ANME-II communities, Environ. Microbiol., 7(1), 98-106, 2005.

Niemann, H., Lösekann, T., de Beer, D., Elvert, M., Nadalig, T., Knittel, K., Amann, R., Sauter, E. J., Schlüter, M., Klages, M., Foucher, J. P., and Boetius, A.: Novel microbial communities of the Haakon Mosby mud volcano and their role as a methane sink, Nature, 443(7113), 854-858, 2006.

Orphan, V. J., House, C. H., Hinrichs, K.-U., McKeegan, K. D., and DeLong, E. F.: Methane-consuming archaea revealed by directly 
coupled isotopic and phylogenetic analysis, Science, 293(5529), 484-487, 2001.

Pallud, C. and Van Cappellen, P.: Kinetics of microbial sulfate reduction in estuarine sediments, Geochim. Cosmochim. Ac., 70, 1148-1162, 2006.

Reeburgh, W. S.: Oceanic methane biogeochemistry, Chem. Rev., 107(2), 486-513, 2007.

Reeburgh, W. S.: "Soft spots" in the global methane budget, in: Microbial Growth on C1 Compounds, edited by: Lidstrom, M. E. and Tabita, F. R., Kluwer, Dordrecht, 334-342, 1996.

Shima, S. and Thauer, R.: Methyl-coenzyme M reductase and the anaerobic oxidation of methane in methanotrophic Archaea, Curr. Opin. Microbiol., 8, 643-648, 2005.

Sauter, E., Muyakshin, S., Charlou, J., Schlüter, M., Boetius, A., Jerosch, K., et al.: Methane discharge from a deep-sea submarine mud volcano into the upper water column by gas hydrate-coated methane bubbles, Earth Planet. Sc. Lett., 243, 354-365, 2006.

Torres, M. E., McManus, J., Hammond, D. E., de Angelis, M. A., Heeschen, K. U., Colbert, S. L., Tryon, M. D., Brown, K. M., and Suess, E.: Fluid and chemical fluxes in and out of sediments hosting methane hydrate deposits on Hydrate Ridge, OR, I: Hydrological provinces, Earth Planet. Sc. Lett., 201, 525-540, 2002.

Treude, T., Boetius, A., Knittel, K., Wallmann, K., and Jørgensen, B. B.: Anaerobic oxidation of methane above gas hydrates at Hydrate Ridge, NE Pacific Ocean. Mar. Ecol.-Prog. Ser., 264, $1-14,2003$.

Treude, T., Knittel, K., Blumenberg, M., Seifert, R., and Boetius, A.: Subsurface microbial methanotrophic mats in the Black Sea, Appl. Environ. Microb., 71(10), 6375-6378, 2005.
Treude, T., Orphan, V., Knittel, K., Gieseke, A., House, C. and Boetius, A.: Consumption of methane and $\mathrm{CO} 2$ by methanotrophic microbial mats from gas seeps of the anoxic Black Sea, Appl. Environ. Microb., 73, 2271-2283, 2007.

Trotsenko, Y. A. and Khmelenina, V. N.: Aerobic methanotrophic bacteria of cold ecosystems, FEMS Microbiol. Ecol., 53(1), 1526, 2005.

Tryon, M. D., Brown, K. M., and Torres, M. E.: Fluid and chemical flux in and out of sediments hosting methane hydrate deposits on Hydrate Ridge, OR, II: Hydrological processes, Earth Planet. Sc. Lett., 201, 541-557, 2002

Wegener, G., Niemann, H., Elvert, M., Hinrichs, K.-U., and Boetius, A.: Assimilation of methane and inorganic carbon by microbial communities mediating the anaerobic oxidation of methane, Environ. Microbiol., 10, 2287-2298, 2008 a.

Wegener, G., Shovitri, M., Knittel, K., Niemann, H., Hovland, M., and Boetius, A.: Biogeochemical processes and microbial diversity of the Gullfaks and Tommeliten methane seeps (Northern North Sea), Biogeosciences, 5, 1127-1144, 2008b, http://www.biogeosciences.net/5/1127/2008/.

Wellsbury, P., Goodman, K., Cragg, A., and Parkes, R. J.: The geomicrobiology of deep marine sediments from Blake Ridge containing methane hydrate (site 994, 995 and 997), Proceedings of the Ocean Drilling Program, Scientific results, 164, 379-391, 2000.

Widdel, F. and Bak, F.: Gram-negative mesophilic sulfate-reducing bacteria, in: The prokaryotes, edited by: Balows, A., Trper, $\mathrm{H}$. G., Dworkin, M., Harder, W., and Schleifer, K.-H., SpringerVerlag, New York, 3352-3378, 1992. 